\title{
ELECTRODE PROCESSES IN ELECTROLYSIS OF ZIRCONIUM AT PRODUCTION OF PLASTIC ZIRCONIUM FOR NUCLEAR ENERGY
}

\author{
A.P. Mukhachev, V.G. Nefedov*, O.A. Kharytonova** \\ Center of Chemical Technologies AINU, Kamenskoe, Ukraine; \\ *Dnieper State University of Chemical Technology, Dnipro, Ukraine; \\ **Dniprovskyi State Technical University, Kamenskoe, Ukraine \\ E-mail:eah@ukr.net
}

\begin{abstract}
The analysis of the conditions for industrial production of zirconium by the electrolysis of a melt of potassium fluorozirconate and potassium chloride in a sealed electrolyzer with a current load of $10 \mathrm{kA}$ was carried out. It is shown that the developed method of preparing the raw material without the use of chlorine, with electrolytic reduction of zirconium provides the production of a metal of nuclear purity, with a hafnium content of less than 0.005 wt. $\%$ polyvalent ion electrodes. The current output of zirconium is $55 \ldots 60 \%$, which may be due to reversible oxidation-reduction on the electrodes of polyvalent ions. The low resistance of the graphite anode is due to both chemical interaction with the released fluorine and chlorine, and its mechanical destruction.
\end{abstract}

\section{INTRODUCTION}

An industrial method of producing plastic zirconium of nuclear purity for the manufacture of products of a wide range of pipes, rods, sheets, wires used as part of nuclear fuel (JF) was developed in the USSR on the basis of the electrolysis of molten salts from the $\mathrm{K}_{2} \mathrm{ZrF}_{6^{-}}$ $\mathrm{KCl}-\mathrm{KF}$ electrolyte. A mixture of fluorocirconate and potassium fluoride salt was first obtained in the process of sintering zircon with potassium fluorosilicate $\left(\mathrm{K}_{2} \mathrm{SiF}_{6}\right)$ at a temperature of $800{ }^{\circ} \mathrm{C}$. To separate zirconium and hafnium, the process of fractional crystallization of their fluorides was mastered, based on the different solubilities of $\mathrm{Zr}$ and $\mathrm{Hf}$ salts in water at a temperature of $90{ }^{\circ} \mathrm{C}$ [1]. Its disadvantages were the low yield of zirconium in an attempt to reduce the content of hafnium in salt from 2 to $0.01 \%$, the production of enriched hafnium concentrate $(6 \ldots 10 \%)$ requiring processing, the presence of solid and liquid wastes requiring disposal.

To extract zirconium when processing zircon more than $70 \%$, it was decided to limit the content of $\mathrm{Hf}$ in the $\mathrm{Zr}$ salt to $0.005 \%$ by weight, which did not meet the requirements of the ASTM standard for zirconium. This limited the sale of zirconium products for export.

Plans for the development of zirconium production in the $70 \mathrm{~s}$ of the twentieth century to a level of $2.0 \ldots 4.0$ thousand tons per year required new, more efficient technological processes for the processing of zircon, which would ensure comprehensive processing of raw materials, with maximum extraction of zirconium and hafnium and obtaining high-purity metals on new technologies for the development of nuclear energy, environmental requirements for environmental protection.

Zircon chloride processing technology operating in the USA [2] under the conditions of Ukraine could not be implemented due to the formation of chloride effluents that cannot be recycled, which was harmful to the environment.

Ukraine had a successful experience in opening zircon by sintering with chalk, which did not have the disadvantages inherent in the processes of chlorination and sintering of zircon with $\mathrm{K}_{2} \mathrm{SiF}_{6}$. Its use at $\mathrm{PChZ}$ allowed us to obtain zirconium and hafnium salts, which are soluble in nitric acid, to extract them on a TBPkerosene extractant to obtain pure $\mathrm{Zr}$ and $\mathrm{Hf}$ salts, without a fractional crystallization process. In this case, $\mathrm{Zr}, \mathrm{K}_{2} \mathrm{ZrF}_{6}$ salt was obtained with a hafnium content of less than $0.005 \%$ and a hafnium salt suitable for producing nuclear-grade hafnium, which reduced the cost of zirconium by $20 \ldots 30 \%$.

Despite the positive experience in the development and implementation of chlorine-free processing technology for zircon, with the production of nucleargrade zirconium alloys on the scale of pilot production of $130 \mathrm{t}$ zirconium per year, Ukraine continues to import zirconium rolled products. Therefore, the choice of the method of obtaining zirconium of nuclear purity from domestic raw materials to replace imports remains relevant.

In this article, the results of the first studies of the electrolysis of potassium fluorocirconate of Ukrainian production were published, the reasons for the low current output of zirconium and the rapid destruction of the anode from graphite were analyzed, the quality of electrolytic zirconium powder was evaluated.

\section{TECHNIQUE OF INDUSTRIAL THEORY OF ELECTROLYSIS OF ZIRCONIUM}

During electrolysis at the cathode, reactions of reduction of zirconium and potassium proceed [3]:

$\mathrm{ZrF}_{6}^{2-}($ fusion $)+4 e \rightarrow \mathrm{Zr}(f e)+6 F^{-}$(fusion $)$

$$
4 K^{-}+4 e \rightarrow 4 K \text {. }
$$

The released potassium partially interacts with potassium fluorozirconate and restores zirconium by the reaction:

$$
\mathrm{K}_{2} \mathrm{ZrF}_{6}+4 \mathrm{~K} \rightarrow \mathrm{Zr}+6 \mathrm{KF} .
$$

The confirmation of this reaction is the appearance of finely dispersed zirconium powder in the cathode product, as well as the accumulation of potassium fluoride in the melt.

The presence of potassium metal in the cathode product was detected during the evolution of hydrogen, as a result of the decomposition of water: 


$$
2 \mathrm{~K}+3 \mathrm{H}_{2} \mathrm{O} \rightarrow 2 \mathrm{KOH}+2 \mathrm{H}_{2} \uparrow .
$$

The release of zirconium at the cathode is preceded by its recovery to the divalent state. Therefore, near the cathode in the melt there is an equilibrium between the metal and its ions of higher and lower valency:

$$
\left.Z r^{4+}(\text { fusion })+Z r(f e) \leftrightarrow 2 Z r^{2+} \text { (fusion }\right)
$$

The equilibrium constant of this reaction is determined from the expression:

$$
\mathrm{K}=\frac{\left[\mathrm{Zr}^{2+}\right]^{2}}{\left[\mathrm{Zr}^{4+}\right]}=\frac{x^{2}}{1-x}[\mathrm{Zr}],
$$

where $x$ is the proportion of divalent zirconium $[\mathrm{Zr}]=$ $\left[\mathrm{Zr}^{2+}\right]+\left[\mathrm{Zr}^{4+}\right]$.

The cathode current density during electrolysis is $3.16 \mathrm{~A} / \mathrm{cm}^{2}$.

At the anode, as a result of strong depolarization, the discharge potential of fluorine ions decreases from 2.93 to $0.9 \mathrm{~V}$, which is lower than the discharge potential of chlorine ions, equal to $1.2 \mathrm{~V}$. When this occurs two electrochemical reactions:

$$
\begin{gathered}
2 \mathrm{Cl}^{-}-2 e \rightarrow \mathrm{Cl}_{2}, \\
2 \mathrm{~F}^{-}+2 \mathrm{C}-2 e \rightarrow 2 C F .
\end{gathered}
$$

When $\mathrm{CF}$ interacts with chlorine, a thermodynamic ally unstable compound $\mathrm{CFCl}$ is formed, which decomposes into a series of more stable freons of composition (where $m=0,1,2,3$ ):

$$
\begin{aligned}
& \mathrm{CF}+1.5 \mathrm{Cl}_{2} \rightarrow \mathrm{CFCl}_{3}, \\
& 2 \mathrm{CF}+\mathrm{Cl}_{2} \rightarrow 2 \mathrm{CFCl}, \\
& 2 \mathrm{CFCl} \rightarrow \mathrm{CF}_{2} \mathrm{Cl}_{2}+C, \\
& 3 \mathrm{CFCl} \rightarrow \mathrm{CF}_{3} \mathrm{Cl}+\mathrm{Cl}_{2}+2 \mathrm{C}, \\
& 4 \mathrm{CFCl} \rightarrow \mathrm{CF}_{4}+2 \mathrm{Cl}_{2}+3 \mathrm{C} .
\end{aligned}
$$

As a result of these reactions, carbon appears in the electrolyte and is captured by $\mathrm{CP}$.

In turn, the appearance of compound $\mathrm{CF}$ at the anode reduces the potential of chlorine discharge from 1.2 to $0.78 \mathrm{~V}$, which provides preferential release of

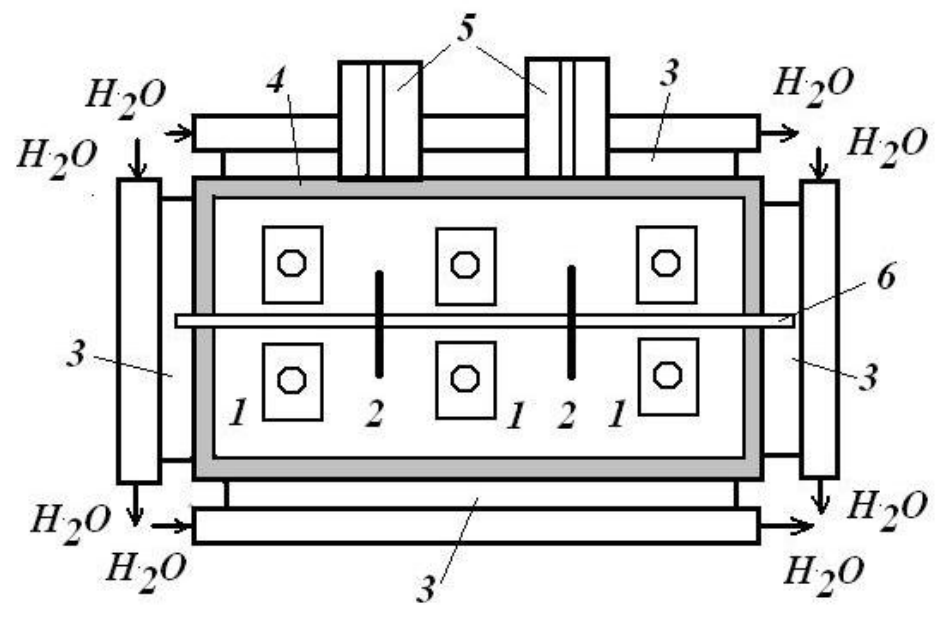

chlorine, the content of which in the anode gas can reach $60 \%$. Anode current density is $0.26 \mathrm{~A} / \mathrm{cm}^{2}$.

Freons F11, F12, F13, F14 containing carbon, chlorine and fluorine are released in proportions determined by the potential for the discharge of ions. Freons are complex reagents and can be used to produce chlorides and metal fluorides in molten salts.

The total reaction of obtaining zirconium powder, accompanied by the destruction of the graphite anode, can be described by the following equation:

$$
\begin{aligned}
& 10 \mathrm{~K}_{2} \mathrm{ZrF}_{6}+19 \mathrm{KCl}+8 \mathrm{C} \pm 42 e \rightarrow \\
& 10 \mathrm{Zr}+37 \mathrm{KF}+2 \mathrm{~K}+\mathrm{CCl}_{3} \mathrm{~F}+2 \mathrm{CCl}_{2} \mathrm{~F}_{2}+ \\
& +2 \mathrm{CClF}_{3}+3 \mathrm{CF}_{4}+5 \mathrm{Cl}_{2} .
\end{aligned}
$$

Analyzes of the composition of the anode gas showed the presence of the amount of freon F-11, F-12, F-13, F-14, chlorine, $\mathrm{CO}, \mathrm{CO}_{2}, \mathrm{O}_{2}$ and $\mathrm{N}_{2}$. Cleaning gas from chlorine was carried out with lime milk. Chloride drains were pumped into the subterranean horizon. Freons, after purification of anode gas from chlorine, were dumped into the atmosphere.

Zirconium powder, which is formed in the process of electrolysis and released in the composition of $\mathrm{CP}$, has a dendrite-like and volume-centered structure. The intergrowths of zirconium crystals have impregnations of the salts that make up the electrolyte containing $\mathrm{KCl}$, $\mathrm{KF}, \mathrm{K}_{2} \mathrm{ZrF}_{6}$. To open large intergrowths, ensuring minimal powder loss, the technological scheme of CP processing includes the following stages: crushing to a fraction $2 \ldots 5 \mathrm{~mm}$, first carbonate treatment with $10 \%$ p-rum ammonium carbonate, grinding to a fraction $1.0 \mathrm{~mm}$. The second carbonate treatment is conducted with a 5\% ammonium carbonate solution. This is followed by water treatment of the powder, its flotation, acid and water washings. Chloride drains are pumped into the underground horizon.

\section{DESCRIPTION OF THE ELECTROLYZER FOR THE ELECTROLYSIS OF ZIRCONIUM}

For electrolytic production of zirconium, an electrolyzer with a current load of $10 \mathrm{kA}$, shown in Figure, is used.

The scheme of the electrolyzer to obtain zirconium.

Cross section: 1 -anode; 2 - cathode; 3 -caisson; 4 - garnissage; 5 - bunker: 6 - shaft, 7 - cutter 
The cell has a rectangular shape. In order to prevent the interaction of the materials of the walls of the electrolyzer with the electrolyte, during the starting period a layer of garnissage with a resistance of $50 \ldots 60 \Omega$ is built up on the walls cooled by water. A shaft with two cathodes is installed along the major axis of the electrolyzer. Three pairs of prefabricated graphite anodes are located near the cathodes. The cathodes in the form of segments are made of steel X18H9T and fixed on a hollow shaft cooled from the inside with a water-air mixture.

After increasing the sediment, once per shift, the cathodes are rotated, and when rotated by $270^{\circ}$, the $\mathrm{CP}$ is cut with knives and dumped into a bunker cooled with argon. The electrolyte is corrected after cutting a CP once a shift is a mixture of salts consisting of $20 \%$ $\mathrm{K}_{2} \mathrm{ZrF}_{6}$, humidity not more than 0.05 and $80 \% \mathrm{KCl}$ with humidity up to $1 \%$. The loading of fluorocirconate and potassium chloride is made by screw feeders from two bunkers.

To maintain a constant electrolyte composition, it is drained daily.

$\mathrm{KP}$ contains zirconium powder, $\mathrm{K}_{2} \mathrm{ZrF}_{6}$, hygroscopic salts of $\mathrm{KCl}$ and $\mathrm{CF}$, which requires careful handling. CP humidification during storage in air can lead to powder burning in closed systems, since zirconium can ignite spontaneously in air at a humidity of less than $10 \%$. Merged electrolyte is cooled, crushed and recycled.

When the electrolyte is drained, the electrolyzer operates in the open mode, so the powder is obtained with a high content of oxygen and nitrogen and undergoes iodide refining.

\section{RESULT AND DISCUSSION \\ 3.1. THE MATERIAL BALANCE OF THE ELECTROLYSIS PROCESS}

It should be noted that in industrial production conditions, mass electrolysis indices inevitably differ from stoichiometric ones. In the process of working in the electrolyte decreases the content of zirconium, chlorine and increases the content of potassium fluoride. The electrolyte in the electrolysis process has a content of, $\mathrm{K}_{2} \mathrm{ZrF}_{6}-16 \%, \mathrm{KCl}-20 \%, \mathrm{KF}-63 \%, \mathrm{C}-1 \%$. The consumption of $\mathrm{K}_{2} \mathrm{ZrF}_{6}$ in the process of electrolysis was $360 \mathrm{~kg} / \mathrm{day}$. Drain molten electrolyte is $200 \mathrm{~kg} / \mathrm{day}$. Electrolyte entrainment with a cathode product is $200 \mathrm{~kg} /$ day. The developed mathematical models [3] made it possible to calculate the consumption of salt components, the yield of the cathode product, the weight of excess electrolyte. The method of automatic control of the flow of salts allowed to stabilize the composition of the electrolyte [4-6]. This allows you to calculate the material balance of the process of electrolysis of zirconium.

$$
\begin{aligned}
& G_{Z r}=\frac{\left(G_{A}-G_{S}-G_{C}\right) M_{Z r}}{M_{K_{2} Z r F_{6}}}= \\
& =\frac{(360-32-32) 92}{283}=105 \mathrm{~kg} / \text { day },
\end{aligned}
$$

where $G_{\mathrm{Zr}}$ is mass of zirconium, accumulating in the electrolyte; $G_{\mathrm{A}}-$ is the mass of $\mathrm{K}_{2} \mathrm{ZrF}_{6}$ in the incoming salt; $G_{\mathrm{S}}$ - is the mass of $\mathrm{K}_{2} \mathrm{ZrF}_{6}$ in the outgoing salt, $G_{\mathrm{C}}$ - is the mass of $\mathrm{K}_{2} \mathrm{ZrF}_{6}$ in the CP cathode sediment mass of cathode sediment; $M$ are molecular masses of substances. The amount of zirconium that is released on the cathode in the form of metal is $105 \mathrm{~kg}$ /day. The content of gaseous impurities in zirconium is: $\mathrm{O}_{2}-$ less than $0.1 \% ; \mathrm{N}_{2}-$ less than $0.005 \%$, which ensures its high plasticity.

\subsection{EVALUATION OF THE CURRENT OUTPUT OF ZIRCONIUM}

\subsubsection{Calculation of the cost of electricity}

The estimated operating time of the electrolyzer is taken $20 \mathrm{~h}$ a day. The amount of electricity passed can be estimated as

$$
Q=I \tau=10000 \times 20=200000 \mathrm{~A} \cdot \mathrm{h} .
$$

The electrochemical equivalent of zirconium, determined from (1), is approximately $0.86 \mathrm{~g} /(\mathrm{A} \cdot \mathrm{h})$. For the specified amount of electricity, according to Faraday's law, $172 \mathrm{~kg}$ of zirconium should stand out. Zirconium current output will be equal to

$$
B=\frac{105}{172}=0.61 \text {. }
$$

\subsubsection{Calculation of the amount of electricity, which} went to the selection of anode products

The amount of transmitted electricity can be determined by the anode process, since it is known the amount of chlorine and freon produced.

Upon receipt of $1 \mathrm{t}$ of zirconium, $0.6 \mathrm{t}$ of chlorine and $1.0 \mathrm{t}$ of freon are released.

Analyzes of the composition of the anode gas showed the following concentrations of freon: F-11 $(5 \pm 1) \%$; F-12 - (4 \pm 1$) \%$; F-3 - $(9 \pm 2) \%$; F-14 $(18 \pm 2) \%$, and chlorine $(57 \pm 3) \%$ with a sum of $\mathrm{Co}$, $\mathrm{CO}_{2}, \mathrm{O}_{2}$, and $\mathrm{N}_{2}$ equal to $5 \%$. Thus, the share of freons in the anode gas is approximately $36 \%$, and the share of each freon in the freon mixture is F-11 - 14\%, F-12 $11 \%, \mathrm{~F}-13-25 \%, \mathrm{~F}-14-50 \%$

Electrochemical equivalents of chlorine and freon F11, F12, F13, and F14 are determined from the total equation using the formula:

$$
k=\frac{v M}{z F}
$$

and make, respectively, $\mathrm{kCl}_{2}=0.33 \mathrm{~g} /(\mathrm{A} \cdot \mathrm{h}), \mathrm{kF11}=0.128 \mathrm{~g} /(\mathrm{A} \cdot \mathrm{h})$; $\mathrm{kF} 12=0.225 \mathrm{~g} /(\mathrm{A} \cdot \mathrm{h}) ; \mathrm{kF} 13=0.195 \mathrm{~g} /(\mathrm{A} \cdot \mathrm{h}) ; \mathrm{kF} 14=0.246 \mathrm{~g} /(\mathrm{A} \cdot \mathrm{h})$.

On the allocation of chlorine is spent, respectively:

$$
Q_{C l 2}=\frac{M}{k_{C l 2}}=\frac{600 \times 10^{3}}{0.33}=1.81 \times 10^{6} \mathrm{~A} \cdot \mathrm{h}
$$

and on the allocation of the amount of freon:

$$
\begin{aligned}
& \mathrm{Q}_{\mathrm{F}}=\frac{\mathrm{M}_{\mathrm{F}}}{\left(\frac{\beta}{k}\right)_{\mathrm{F} 11}+\left(\frac{\beta}{k}\right)_{\mathrm{F} 12}+\left(\frac{\beta}{k}\right)_{\mathrm{F} 13}+\left(\frac{\beta}{k}\right)_{\mathrm{F} 14}}= \\
& =\frac{10^{6}}{4.88}=0,205 \times 10^{6} \mathrm{~A} \cdot \mathrm{h} .
\end{aligned}
$$

The total amount of electricity in (18) and (19) is $2.09 \cdot 10^{6} \mathrm{~A} \cdot \mathrm{h}$.

To get one ton of zirconium should go (19) electricity: 


$$
Q_{Z r}=\frac{M_{Z r}}{k_{Z r}}=\frac{1000 \times 10^{3}}{0.86}=1.176 \cdot 10^{6} \mathrm{~A} \cdot \mathrm{h}
$$

The current output in this case will be:

$$
\mathrm{B}=\frac{1.176 \times 10^{6}}{2.09 \times 10^{6}}=0.56,
$$

which is close enough to (16).

The material balance of the electrolysis process indicates that the low current efficiency of zirconium cannot be associated with metal losses during the electrolysis and processing stages. We believe that in addition to the electrode reactions described in Section 2 , redox processes may occur on the electrodes. For example, the reduction of tetravalent zirconium at the cathode to a bivalent state by reaction (5), its transfer by convective currents to the anode, followed by oxidation to tetravalent. In addition, a certain change in the magnitude of the zirconium current output may be due to a change in the stoichiometric ratio of Freon F11, F12, F13, and F14. So, in the conditions of allocation only F11, the amount of electricity for its allocation will be about $0.78 \cdot 10^{6} \mathrm{~A} \cdot \mathrm{h}$, and the total amount of electricity is only $2.59 \cdot 10^{6} \mathrm{~A} \cdot \mathrm{h}$. The current output of zirconium, calculated according to 3.2.2. in this case will reach $55 \ldots 60 \%$.

A change in the composition of freons formed in different electrolysis modes is confirmed experimentally. So, with the anodic effect, the content of F14 significantly increases, which indicates a high concentration of $\mathrm{CF}$ in the electrolyte and the need for its partial removal. The output of zirconium in KP is significantly reduced.

The current output is significantly reduced.In general, it can be noted that the electrolysis of $\mathrm{K}_{2} \mathrm{ZrF}_{6}$, with a Hf content of less than $0.005 \%$, provided the production of zirconium powder of the same degree of purity as for hafnium, while the purity of zirconium was $99.9 \%$.

\subsubsection{Evaluation of the quality of zirconium powder}

Processing KP according to the above scheme allows you to extract in the finished product $80 \%$ of the powder corresponding to THE 95.259-88. $20 \%$ of fine zirconium powder contaminated with impurities is sent for recycling. The content of metal impurities in the powder corresponds to ASTM B349-80, and the content of hafnium is less than $0.005 \%$, while the silicon content was two times less. The granulometric composition of the powder corresponded to the powder of the standard product. In general, it can be noted that the purity of zirconium was $99.9 \%$. The quality of the powder depends on the quality of the original zirconium salt. In the process of electrolysis, additional metallic impurities are not introduced.

\subsection{ANALYSIS OF THE CONDITION OF COMBUSTION OF A GRAPHITE ANODE}

The destruction of anodes from graphite EG-0 is the inevitable result of the process of electrolysis in chloride-fluoride melts and determines its duration. The formation of freons F11, F12, F13, and F14 according to reactions (8)-(13) occurs on the anode surface and is accompanied by the release of carbon into the melt in quantities of 1, 2, and 3 moles per mole of freons F12,
F13, and F14, respectively. Taking into account the stoichiometric coefficients in equation (14), this means that an additional 15 moles of carbon are involved in the reaction. They can remain on the surface or stand out in a fine state and accumulate in the electrolyte. If we assume that these 15 moles of carbon are emitted in a finely dispersed form, then the calculation of carbon consumption should be made not by 8 , but by 23 moles. Then the value of the electrochemical carbon equivalent will be:

$$
k_{C}=\frac{23 \times 12}{40 \times 26.8}=0.257 \mathrm{~g} /(\mathrm{A} \cdot \mathrm{h}) .
$$

The consumption of carbon (graphite) in the reaction of release of freon according to (14) is

$$
\mathrm{M}_{\mathrm{C}}=\mathrm{Q}_{\mathrm{F}} \mathrm{k}_{\mathrm{C}}=1.26 \times 10^{6} \times 0.257=324 \mathrm{~kg} \text {. }
$$

Let's analyze the obtained values.

Industrial measurements have shown that the specific consumption of graphite is approximately $600 \mathrm{~kg}$ per $1 \mathrm{t}$ of powder. If all the carbon involved in the formation of freon goes into an electrolyte in a fine form, the destruction of the anodes is not exhausted by this process. The assumption that the loss of anode material due to the combustion of graphite when interacting with oxygen (as in the production of aluminum or magnesium) is unlikely due to the low humidity of the raw materials used. Most likely, when freons are released on an inhomogeneous electrode surface, mechanical destruction of graphite occurs with the accumulation of scree in the electrolyte. The carbon content in the powder is limited by a limit of $0.02 \%$ of the mass, therefore, in the washing processes, the zirconium is necessarily cleaned from carbon by the flotation method. The flotation product containing fine fractions of powder and carbon is recycled.

The participation of carbon in the anode process requires the replacement of anodes after 50 days of continuous electrolysis.

\section{CONCLUSIONS}

1. It is shown that the process of electrolysis of zirconium from salt $\mathrm{K}_{2} \mathrm{ZrF}_{6}$ obtained after estractional separation of zirconium and hafnium, retains the content of hafnium in zircon less than $0.005 \%$, which meets the requirements of ASTM B349-80. Zirconium powder has a purity of $99.9 \%$.

2. During electrolysis of fluoride-chloride electrolytes, the current efficiency of zirconium is $55 \ldots 60 \%$. The relatively low current efficiency may be associated with redox processes at the electrodes of polyvalent zirconium ions.

3. Consumption of anode material is determined by its chemical interaction with fluorine and chlorine, and mechanical destruction.

4. Accumulation of KF and release of chlorine at the anode are side effects of electrode processes.

\section{REFERENCES}

1. Khimiya $i$ tekhnologiya redkikh $i$ rasseyannykh elementov / Pod red. K.A. Bol'shakova v 3-kh tomakh: Ucheb. posobie dlya vuzov. M.: "Vysshaya shkola", 1976, p. 320 (in Russian). 
2. N.V. Baryshnikov, V.E. Geger, N.D. Denisova et al. Metallurgiya tsirkoniya i gafniya / Pod red. L.G. Nekhamkina. M: "Metallurgiya", 1979, p. 208 (in Russian).

3. M.V. Smirnov, V.E. Komarov, A.P. Barabashkin. Elektrokhimiya rasplavlennykh solevykh i tverdykh elektrolitov // Trudy instituta elektrokhimii UF AN SSSR. Sverdlovsk, 1961 (in Russian).

4. V.P. Baklanov, V.N. Bezumov, N.A. Matyushkin, A.I. Dunaev. Raschet teplovogo balansa dlya protsessa elektroliza $\mathrm{v}$ germetichnykh garnisazhnykh elektrolizerakh // Tsvetnaya metallurgiya. 2003, N 7, p. 18-27 (in Russian).
5. A.K. Shikov, A.A. Kabanov V.N. Bezumov, et al. Povyshenie effektivnosti elektroliticheskogo usileniya tsirkoniya // Tsvetnye metally. 2011, N 3, p. 47-49 (in Russian).

6. V.P. Baklanov, L.V. Ogorodnikov, E.P. Semenovykh, V.B.Suslov, et al. Opyt sozdaniya avtomatizirovannoy sistemy kontrolya i upravleniya protsessom elektroliticheskogo polucheniya tsirkoniya na baze ispol'zovaniya instrumental'nogo paketa Trace Mode // Promyshlennye ASU i kontrolery. 2004, N 6, p. 13-15 (in Russian).

Article received 14.01.2019

\title{
ЭЛЕКТРОДНЫЕ ПРОЦЕССЫ В ЭЛЕКТРОЛИЗЕ ЦИРКОНИЯ ПРИ ПРОИЗВОДСТВЕ ПЛАСТИЧЕСКОГО ЦИРКОНИЯ ДЛЯ ЯДЕРНОЙ ЭНЕРГИИ
}

\author{
А.П. Мухачев, В.Г. Нефедов, Е.А. Харитонова
}

Проведен анализ условий промышленного получения циркония электролизом расплава фторцирконата калия и хлорида калия в герметичном электролизере с токовой нагрузкой 10 кА. Показано, что разработанный метод подготовки сырья без применения хлора с электролитическим восстановлением циркония обеспечивает получение металла ядерной чистоты с содержанием гафния менее 0,005 мас.\%. Выход по току циркония составляет $55 \ldots 60 \%$, что может быть связано с обратимым окислением-восстановлением на электродах поливалентных ионов. Невысокая стойкость графитового анода обусловлена как химическим взаимодействием с выделяющимися фтором и хлором, так и механическим его разрушением.

\section{ЕЛЕКТРОДНІ ПРОЦЕСИ У ЕЛЕКТРОЛІЗІ ЦИРКОНІЮ ПРИ ВИРОБНИЦТВІ ПЛАСТИЧНОГО ЦИРКОНІЮ ДЛЯ ЯДЕРНОЇ ЕНЕРГЕТИКИ}

\section{А.П. Мухачов, В.Г. Нефьодов, О.А. Харитонова}

Проведено аналіз умов промислового отримання цирконію електролізом розплаву фторцірконата калію і хлориду калію в герметичному електролізері зі струмовим навантаженням 10 кА. Показано, що розроблений метод підготовки сировини без застосування хлору з електролітичним відновленням цирконію забезпечує отримання металу ядерної чистоти 3 вмістом гафнію, менш 0,005 мас.\%. Вихід по струму цирконію становить $55 \ldots 60 \%$, що може бути пов'язано з оборотним окисленням-відновленням на електродах полівалентних іонів. Невисока стійкість графітового анода обумовлена як хімічною взаємодією 3 фтором $\mathrm{i}$ хлором які виділяються, так і механічним його руйнуванням. 